ACTA AGROBOTANICA

Vol. 59, z. $1-2006$

s. $147-154$

\title{
The biological value of pollen of some blackcurrant cultivars (Ribes nigrum L.)
}

\author{
BOŻENA DENISOW \\ Department of Botany, The Laboratory of Horticultural Plant Biology, \\ Agricultural University \\ 20-950 Lublin, 15 Akademicka str., \\ email: bozena.denisow@ar.lublin.pl
}

(Received: 30.05 .2005$)$

\section{Summary}

The studies were carried out in 1994-1997. The experimental bushes were grown in Puławy. Eight cultivars were examined (,Ben Alder', ,Ben Lomond', ,Ben Nevis', ,Ben Tirran', ,Ceres', ,Ojebyn', ,Titania', ,Triton’). Pollen grains viability was estimated in acetocarmine slides, while germination ability was estimated on agar medium. All cultivars showed high viability (80-100\%). Weather conditions (especially temperatures at the time of blooming) had significant influence on germination ability. In colder years, only $10-40 \%$ of pollen produced pollen tubes, while in warmer years $50-80 \%$. The biological value of blackcurrant pollen grains can be more effectively estimated on the basis of their ability to form pollen tubes than their viability.

Key words: blackcurrant (Ribes nigrum L.), viability, germination

\section{INTRODUCTION}

The majority of orchard cultivars require inter-varietal cross-pollination in order to give good fruit yield, which means that the appropriate choice of genetically compatible pollenizer is essential. Commonly cultivated clones of blackcurrant are highly self-fertile, and can develop fruits when their own pollen has reached the stigma (Kołtowski et a 1., 1997; D e n is ow, 2003). The proper fertilization process of blackcurrant depends, among other factors, on the amount of pollen which reaches the stigma (L e c h , 1976, 2000; L e c h et al., 1997; D e n i s o w, 2002). The appropriate pollen transfer and pollination is guaranteed by insects, especially honey-bee 
( u cka et $a$., 1972; Kołtowski et al., 1997; Den is ow, 2003). Both inaccurate and ineffective fertilization may cause a substantial loss of yield. Apart from structural, genetic, physiological and cytological factors the correct progress of fertilization is determined by the biological value of pollen, its viability, germination and the rate of pollen tubes growth (Wo c i ó r, 1976; Ś n i eżk o, 1991, 1993; S z k lan o w s k a et al., 1997; $\dot{Z}$ e b row s ka, 1997; K a c z mar s ka, 2003). Therefore, it seems advisable to estimate the pollen grains fertility of commonly cultivated blackcurrant cultivars and those which are used in breeding.

The aim of this study has been to estimate the viability and germination ability of some blackcurrant cultivars. The diameter of pollen grains has also been measured.

\section{MATERIAL AND METHODS}

In the experiment which was carried out in 1994-1997, the bushes of eight blackcurrant cultivars (Ribes nigrum L.) grown in Puławy were examined. Viability and germination ability of pollen were estimated in the case of mid-early blooming (Ceres, Ben Lomond, Ben Nevis, Ojebyn, Titania, Triton), and late blooming (Ben Alder, Ben Tirran) cultivars. The analysed pollen grains were always gathered at the full blooming stage. Viability analyses were carried out in two slides for each cultivar. Fresh pollen was stained with $2 \%$ acetocarmine with glycerine solution (1:1). The pollen grains filled with cytoplasm i.e. those which were coloured red, were treated as viable, whereas uncoloured pollen grains without cytoplasm were treated as non-viable. The number of viable and non-viable grains was counted up to 300 grains for each slide, and then the percentage share of viable grains was established. Pollen germination ability, i.e. the percentage of grains which produce pollen tubes, was calculated on a newly prepared medium consisting of $12.5 \%$ agar and $0.6 \%$ saccharose. The count was done after 24 hours. The slides were stored in a damp tissue in Pettrie glass, in $22^{\circ} \mathrm{C}$. Grains with pollen tubes and those without were counted up to 300 grains for each cultivar. The percentage ratio of germinating to viable grains was also calculated. Additionally, the size of pollen grains estimated on the basis of diameter measurement was established in 1994 and 1997. Pollen which was first treated by ether and ethyl alcohol $96 \%$ was measured in glycerin jelly slides. The diameter of 50 grains was measured in each slide prepared separately for eight cultivars.

All measurements of blackcurrant pollen were made on the light microscope MB 30S under 10x40 magnification. For pollen size measurements the microscope glass was additionally supplied with a specially adopted scale.

Weather conditions. In 1994 and 1995 air temperatures in Puławy in the period of blooming of blackcurrant cultivars were lower than long-term average. April was dry with the number of sunny hours reaching the long-term average. In 1996 and 1997 the spring was late, but it was warm and dry. Air temperatures at the time of blooming 
were higher than long-term average. This caused a very dynamic growth and development of flower buds as well as blooming.

The results of the experiment are shown in tables were the appropriate averages and standard deviation values can be found. The results were analysed by double factor ANOVA. The significance of differences was tested by Duncan test. The level of significance was taken at 0.05 .

\section{RESULTS}

The viability of blackcurrant pollen grains showed little differentiation between examined cultivars. The pollen grains viability reached $92.3-95.4 \%$ on average (tab. 1). Only Ben Lomond showed slightly lower viability, i.e. $89.3 \%$. In the first and second year of the experiment $(1994,1995)$ in comparison with the following years $(1996,1997)$ the percentage of non-viable grains was higher for all cultivars (10-20\% higher). This applied especially to Ben Lomond, Ben Alder and Triton. Germination ability on agar medium proved to be more varied than its viability. The mean values of this feature differed significantly between cultivars and different years of experiment. The lowest germination ability (20-40\%) was observed in 1994-1995. The pollen of cv. Ceres produced only $10 \%$ of pollen grains with pollen tubes. The germination ability in 1996-1997 was significantly higher and varied from 50\% (Ojebyn) to $80 \%$ (Ben Alder, Ben Tirran). The observed differences between cultivars as far as biological value of pollen is concerned, expressed as its viability and germination ability, were probably caused by bad weather conditions, especially rapid temperature changes at the time of microsporogenesis and pollen tubes growth.

The established ratio of germination to viability indicate the percentage of viable pollen grains able to form pollen tubes. This value for blackcurrant cultivars varied from $11 \%$ to $86 \%$. The lowest value (27-32\%) was observed in 1994 and 1995 , which was connected with the low ability of pollen for pollen tubes growth, although pollen viability was up to $80 \%$. In other years of study (1996-1997) the germination to viability ratio indicated that approx. $70 \%$ of viable grains could produce pollen tubes.

Pollen grains of blackcurrant cultivars were non-angular and circular in shape and showed little variation in size (tab. 2). Most cultivars were characterised by medium size grains. Small pollen grains were rarely observed, especially in the pollen of cultivars Ben Nevis and Ceres. Considerably bigger pollen grains were observed for the analysed cultivars in the first year of study $(29.14 \mu \mathrm{m}$ on average). This result must have been connected with better conditions of growth and better nutrition of grains by tapetum tissue. 
Table 1

Viability, germination and potential energy of pollen of eight cultivars of blackcurrant in 1994-1997.

\begin{tabular}{|c|c|c|c|c|c|c|}
\hline Cultivar & Year & Viability \% & $\pm \mathrm{SD}$ & $\begin{array}{c}\text { Germination } \\
\%\end{array}$ & $\pm \mathrm{SD}$ & $\begin{array}{c}\text { Potential } \\
\text { energy } \\
\%\end{array}$ \\
\hline \multirow{5}{*}{ Ben Alder } & 1994 & $88.0 \mathrm{a}$ & 0.4 & $33.0 \mathrm{e}-\mathrm{g}$ & 4.8 & 37.5 \\
\hline & 1995 & 91.4 b-e & 1.1 & $31.5 \mathrm{~d}-\mathrm{g}$ & 5.5 & 34.5 \\
\hline & 1996 & $93.6 \mathrm{~b}-\mathrm{g}$ & 1.1 & $78.5 \mathrm{k}$ & 3.0 & 83.8 \\
\hline & 1997 & $97.5 \mathrm{bi}$ & 0.8 & $80.9 \mathrm{k}$ & 2.1 & 82.9 \\
\hline & average & $92.6 \mathrm{BC}$ & & $55.9 \mathrm{C}$ & & 59.7 \\
\hline \multirow{5}{*}{ Ben Lomond } & 1994 & $81.5 \mathrm{a}$ & 1.4 & $24.0 \mathrm{c}-\mathrm{d}$ & 3.7 & 29.4 \\
\hline & 1995 & 80.8 a & 1.3 & $19.2 \mathrm{~b}-\mathrm{c}$ & 2.0 & 23.7 \\
\hline & 1996 & $95.0 \mathrm{~d}-\mathrm{h}$ & 1.5 & $75.8 \mathrm{j}-\mathrm{k}$ & 3.0 & 79.8 \\
\hline & 1997 & $99.5 \mathrm{~h}$ & 0.6 & $74.9 \mathrm{j}-\mathrm{k}$ & 1.2 & 75.3 \\
\hline & average & $89.2 \mathrm{~A}$ & & $48.5 \mathrm{~B}$ & & 52.1 \\
\hline \multirow{5}{*}{ Ben Nevis } & 1994 & 94.6 b-h & 0.4 & $24.0 \mathrm{c}-\mathrm{e}$ & 4.5 & 25.4 \\
\hline & 1995 & $95.8 \mathrm{~d}-\mathrm{h}$ & 1.1 & $26.7 \mathrm{c}-\mathrm{f}$ & 3.2 & 27.9 \\
\hline & 1996 & $93.3 \mathrm{c}-\mathrm{h}$ & 1.0 & $64.7 \mathrm{ij}$ & 3.5 & 69.3 \\
\hline & 1997 & $98.0 \mathrm{~h}$ & 1.0 & $73.7 \mathrm{jk}$ & 2.2 & 75.2 \\
\hline & average & $95.4 \mathrm{CD}$ & & $47.3 \mathrm{~B}$ & & 49.5 \\
\hline \multirow{5}{*}{ Ben Tirran } & 1994 & 88.8 b-f & 0.7 & $41.5 \mathrm{~g}$ & 3.0 & 46.7 \\
\hline & 1995 & 87.5 b-d & 0.8 & $25.0 \mathrm{c-e}$ & 2.3 & 28.6 \\
\hline & 1996 & $91.3 \mathrm{~b}$-f & 1.1 & $77.0 \mathrm{k}$ & 3.3 & 84.3 \\
\hline & 1997 & $99.5 \mathrm{~h}$ & 1.0 & $81.6 \mathrm{k}$ & 3.6 & 82.0 \\
\hline & average & $91.8 \mathrm{~B}$ & & $56.3 \mathrm{C}$ & & 60.4 \\
\hline \multirow{5}{*}{ Ceres } & 1994 & 94.6 ef & 2.3 & $11.8 \mathrm{ab}$ & 3.8 & 12.5 \\
\hline & 1995 & 88.8 b-d & 1.6 & $9.5 \mathrm{a}$ & 2.8 & 10.7 \\
\hline & 1996 & $99.8 \mathrm{~h}$ & 1.8 & $62.5 \mathrm{hi}$ & 3.0 & 62.6 \\
\hline & 1997 & $95.3 \mathrm{~d}-\mathrm{h}$ & 1.7 & $61.7 \mathrm{i}$ & 1.1 & 64.7 \\
\hline & average & $94.6 \mathrm{D}$ & & $36.4_{\mathrm{A}}$ & & 37.6 \\
\hline \multirow{5}{*}{ Ojebyn } & 1994 & $92.5 \mathrm{~b}-\mathrm{g}$ & 2.1 & $32.5 \mathrm{e}-\mathrm{g}$ & 4.4 & 35.1 \\
\hline & 1995 & 91.6 b-f & 1.1 & $37.0 \mathrm{fg}$ & 5.1 & 40.4 \\
\hline & 1996 & $99.5 \mathrm{~h}$ & 0.5 & $53.3 \mathrm{~h}$ & 3.4 & 53.6 \\
\hline & 1997 & $96.3 \mathrm{~b}-\mathrm{i}$ & 1.0 & $51.4 \mathrm{~h}$ & 2.8 & 53.4 \\
\hline & average & $94.9 \mathrm{CD}$ & & $43.6 \mathrm{~B}$ & & 45.6 \\
\hline \multirow{5}{*}{ Titania } & 1994 & $91.5 \mathrm{~b}-\mathrm{g}$ & 1.2 & $24.8 \mathrm{e}-\mathrm{g}$ & 1.4 & 27.1 \\
\hline & 1995 & $93.3 \mathrm{c}-\mathrm{h}$ & 4.1 & $11.3 \mathrm{ab}$ & 2.2 & 12.1 \\
\hline & 1996 & $97.6 \mathrm{~g}-\mathrm{h}$ & 2.1 & $75.3 \mathrm{k}$ & 6.7 & 77.2 \\
\hline & 1997 & $95.8 \mathrm{~d}-\mathrm{h}$ & 0.7 & $67.9 \mathrm{jk}$ & 3.2 & 70.9 \\
\hline & average & $94.6 \mathrm{CD}$ & & 44.8 в & & 46.8 \\
\hline \multirow{5}{*}{ Triton } & 1994 & $87.5 \mathrm{bc}$ & 1.4 & $33.3 \mathrm{~d}-\mathrm{g}$ & 4.3 & 38.1 \\
\hline & 1995 & $86.8 \mathrm{~b}$ & 1.6 & $31.0 \mathrm{dg}$ & 3.5 & 35.7 \\
\hline & 1996 & $97.7 \mathrm{f}-\mathrm{h}$ & 2.2 & $58.4 \mathrm{hi}$ & 1.2 & 59.8 \\
\hline & 1997 & $98.5 \mathrm{~h}$ & 2.1 & $61.1 \mathrm{hi}$ & 0.8 & 62.0 \\
\hline & average & $92.6 \mathrm{~B}$ & & $45.9 \mathrm{~B}$ & & 48.9 \\
\hline \multirow{5}{*}{$\begin{array}{l}\text { average } \\
\text { in years }\end{array}$} & 1994 & $89.9_{\mathrm{A}}$ & & 28.1 в & & 31.5 \\
\hline & 1995 & $89.5 \mathrm{~A}$ & & $23.9_{\mathrm{A}}$ & & 26.7 \\
\hline & 1996 & 95.9 в & & $68.2_{\mathrm{C}}$ & & 71.3 \\
\hline & 1997 & $97.6_{B}$ & & $69.2 \mathrm{c}$ & & 70.8 \\
\hline & average & $93.2^{B}$ & & 47.4 & & 50.1 \\
\hline
\end{tabular}

Averages followed by the same letters are not different at $\alpha=0.05$ by Duncan test 
Table 2

Size of pollen grains of 8 cultivars of blackcurrant (data from 1994 and 1997).

\begin{tabular}{|c|c|c|c|c|}
\hline \multirow{2}{*}{ Cultivar } & \multirow{2}{*}{ Year } & \multicolumn{3}{|c|}{ Diameter in $\mu \mathrm{m}$} \\
\hline & & $\min$ & $\max$ & Mean \\
\hline \multirow{3}{*}{ Ben Alder } & 1994 & 27.0 & 33.0 & 30.28 \\
\hline & 1997 & 24.0 & 30.0 & 27.97 \\
\hline & average & & & 29.13 \\
\hline \multirow{3}{*}{ Ben Lomond } & 1994 & 25.5 & 30.0 & 28.45 \\
\hline & 1997 & 25.5 & 30.0 & 28.52 \\
\hline & average & & & 28.49 \\
\hline \multirow{3}{*}{ Ben Nevis } & 1994 & 24.0 & 30.0 & 28.59 \\
\hline & 1997 & 21.0 & 30.0 & 28.05 \\
\hline & average & & & 28.32 \\
\hline \multirow{3}{*}{ Ben Tirran } & 1994 & 24.0 & 30.0 & 29.20 \\
\hline & 1997 & 24.0 & 30.0 & 27.35 \\
\hline & average & & & 28.27 \\
\hline \multirow{3}{*}{ Ceres } & 1994 & 24.0 & 33.0 & 28.94 \\
\hline & 1997 & 24.0 & 30.0 & 27.93 \\
\hline & average & & & 28.44 \\
\hline \multirow{3}{*}{ Ojebyn } & 1994 & 27.0 & 33.0 & 29.73 \\
\hline & 1997 & 27.0 & 33.0 & 28.93 \\
\hline & average & & & 29.33 \\
\hline \multirow{3}{*}{ Titania } & 1994 & 27.0 & 33.0 & 29.40 \\
\hline & 1997 & 27.0 & 30.0 & 28.45 \\
\hline & average & & & 28.93 \\
\hline \multirow{3}{*}{ Triton } & 1994 & 27.0 & 30.0 & 28.53 \\
\hline & 1997 & 24.0 & 30.0 & 27.84 \\
\hline & average & & & 28.18 \\
\hline \multirow{3}{*}{ Average in years } & 1994 & & & 29.14 \\
\hline & 1997 & & & 28.13 \\
\hline & average & & & 28.63 \\
\hline
\end{tabular}

\section{DISCUSSION}

The paper presents the results of the study of biological value of eight cultivars of blackcurrant. Pollen viability was $80-100 \%$ and did not differ from the results obtained by S z k 1 a n o w sk a et. al., 1997. The viability did not significantly depend on cultivar which indicates that genetic factors have little influence on viability of pollen of blackcurrant, unlike in the case of cherry and strawberry cultivars, whose pollen shows significant (20-95\%) differentiation of viability between cultivars (Wo c iór, 1976; K a c z mar s ka, 2003). 
Germination ability showed a lot of differentiation in consecutive years of the experiment as well as between different cultivars. The pollen of all cultivars germinated best (70\%) in 1996-1997 when just before and at the time of blooming temperatures were high. Germination was weaker (30\%) in 1994 and 1995 when temperature were lower, which confirms the results of $\mathrm{Szk}$ la n o w s k a et al. (1997). My results corroborate the opinion of W o c i o r (1976) about a significant influence of external factors on functionality of pollen, i.e. its ability to participate in fertilization process.

Germination ability was examined in vitro conditions, which probably explains why the results differ from those obtained by $€ \mathrm{uck}$ a et.al., (1972) and L e c h (1976), who examined germination in vivo straight on stigmas and observed almost $100 \%$ of pollen tubes. Additionally, their experiments applied to different cultivars and were carried out in different years. As is well-known, pollen viability does not coincide with its germination ability especially in in vitro conditions, therefore in this study I tried to establish whether viability and germination ability would differ between cultivars. The calculated ratio of germination ability to viability better shows the biological value of pollen because not all grains with protoplast form pollen tubes. This means that viable pollen grains will not always be effective in fertilization of ovules. The functionality of pollen was used previously by Wo c i ó r (1976) in his study of cherry pollen.

Pollen grains of all examined cultivars were non-angular. The measurements of diameter, which ranged between $28.18 \mu \mathrm{m}-29.33 \mu \mathrm{m}$, allowed to classify them as medium sized according to D y a k ow s k a (1959) classification.

The pollen grain size does not exceed the limits which are given by $\mathrm{Z}$ a n d e r (1935) and Wrońska-Pilarek (1998) Pollen grains of all cultivars are characterised by circular shape, in accordance with the descriptions given by the above mentioned authors.

\section{CONCLUSIONS}

1. The pollen of the examined blackcurrant cultivars was characterised by high viability $80-100 \%$ irrespective of the particular cultivar.

2. External factors influenced the ability for germination. Germination ability was $10-40 \%$ in colder years and $50-80 \%$ in warmer years.

3. The ratio of germination to viability (decisive for pollen value in fertilization) was similar to germination ability and reached $30 \%$ in colder years and $60 \%$ in warmer years.

4. Circular pollen grains of blackcurrant cultivars show little variation of diameter. 


\section{REFERENCES}

D e $\mathrm{n}$ is ow B., 2002. The influence of the degree of pollination of black currant flowers $(R i-$ bes nigrum L.) on the number of seeds and its size. Ann. Univ. Mariae Curie Skłodowska sect. E. 10, 59-64.

D e n i s ow B., 2003. Self-pollination and self-fertility in eight cultivars of black currant (Ribes nigrum L.). Acta Biol. Cracov. s. Botanica, 45(1): 111-114.

D yakowska J., 1959. Podręcznik palinologii. Metody i problemy. Wyd. Geologiczne, Warszawa: 192.

K a c z m a r s k a E., 2003. Żywotność pyłku i wiązanie nasion u wybranych odmian truskawki (Fragaria x ananasa Duch.). Acta Sci. Pol. Hortorum Cultus, 2(1): 111-116.

Kołtowski Z., Jabłoński B., Szklanowska K., Pluta S., 1997. Wpływ owadów zapylających na plonowanie ważniejszych odmian porzeczki czarnej (Ribes nigrum L.). Pszczeln. Zesz. Nauk. 41: 19-41.

L e c h W., 1976. Przebieg zapylenia i zapłodnienia u odmian porzeczki czarnej. Acta Agraria et Silvestria, 16: 82-95.

L e c h W., 2000. Floral biology of fruit trees and bushes. Bot. Guidebooks, 24: 195-225.

Lech W., Małodobry M., Dziedzic E., Bieniasz M., 1997. Badania dotyczące zapylania i zapłodnienia roślin sadowniczych. I Ogólnop. Konf. Nauk. „Biologia kwitnienia, nektarowania i zapylania roślin”. 13-14 XI Lublin: 66-71.

Łucka M., Le ch W., D or os ińska K., 1972. Przebieg procesu zapylania i badanie stopnia samopylności u porzeczki czarnej. Zesz Nauk. WSR Kraków, 70(2): 89-101.

S zk la now ska K., Jabłoński B., Kołtowski Z., 1997. Wydajność pyłkowa ważniejszych odmian porzeczki czarnej (Ribes nigrum L.). Pszczeln. Zesz Nauk. 41: 33-41.

Śn ieżko R., 1991. Pylniki i pyłek w hodowli in vitro. Wiad. Bot. 35(1): 23-33.

Śnieżk o R., Wi eniarczyk K., 1993. Znamię i pyłek - przegląd prac dotyczących zgodnego zapylania. Wiad. Bot. 37(1/2): 31-41.

W o c i ó r S., 1976. Badania biologii pyłku wytwarzanego przez kwiaty wiśni zakwitające w różnych fazach kwitnienia. Acta Agrobot. 21: 69-84.

Wrońska-Pilarek D., 1998. Morfologia ziaren pyłku krajowych gatunków z rodzaju Ribes L. Mat. Konf. 51 Zjazd PTB. Gdańsk: 542.

Z ander O., 1935. Pollengestaltung und Herkunftsbestimmung bei Blutenhonig. Band I. Verlag, Berlin, 167-168.

Z e brow s k J J., 1997. Factors affecting pollen grain viability in the strawbery (Fragaria $x$ ananassa Duch.). J. Hort. Sci. 72: 213-219. 


\title{
Wartość biologiczna pyłku wybranych odmian porzeczki czarnej (Ribes nigrum L.)
}

\begin{abstract}
Streszczenie
Badania prowadzono w latach 1994-1997. Krzewy doświadczalne porzeczki czarnej rosły na terenie PZD w Puławach. Wytypowano 8 odmian (Ben Alder, Ben Lomond, Ben Nevis, Ben Tirran, Ceres, Ojebyn, Titania, Triton). Żywotność pyłku oceniano w preparatach acetokarminowych, a zdolność kiełkowania na pożywce agarowej. Wszystkie odmiany charakteryzowały się wysoką żywotnością (80-100\%). Stwierdzono duży wpływ czynników atmosferycznych, zwłaszcza panującej w okresie kwitnienia temperatury, na zdolność kiełkowania pyłku. W latach o niskiej temperaturze tylko $10-40 \%$ pyłku wytwarzało łagiewki, a podczas wyższych temperatur w czasie kwitnienia 50-80\%. Dla oceny wartości biologicznej pyłku porzeczki czarnej bardziej przydatna jest ocena jego zdolności do wytwarzania łagiewek pyłkowych niż żywotności.
\end{abstract}

